\title{
DEVELOPING NON-DESTRUCTIVE METHODS TO DETERMINE NATAL ORIGINS OF SNAKE RIVER CUTTHROAT TROUT IN THE JACKSON LAKE WATERSHED
}

\author{
SCOTT A. CARLETON $\downarrow$ COOPERATIVE FISH \& WILDLIFE RESEARCH UNIT \\ NEW MEXICO STATE UNIVERSITY — LAS CRUCES, NM \\ JIM HOBBS $\uparrow$ WILDLIFE, FISH \& CONSERVATION BIOLOGY \\ UNIVERSITY OF CALIFORNIA $\uparrow$ DAVIS, CA
}

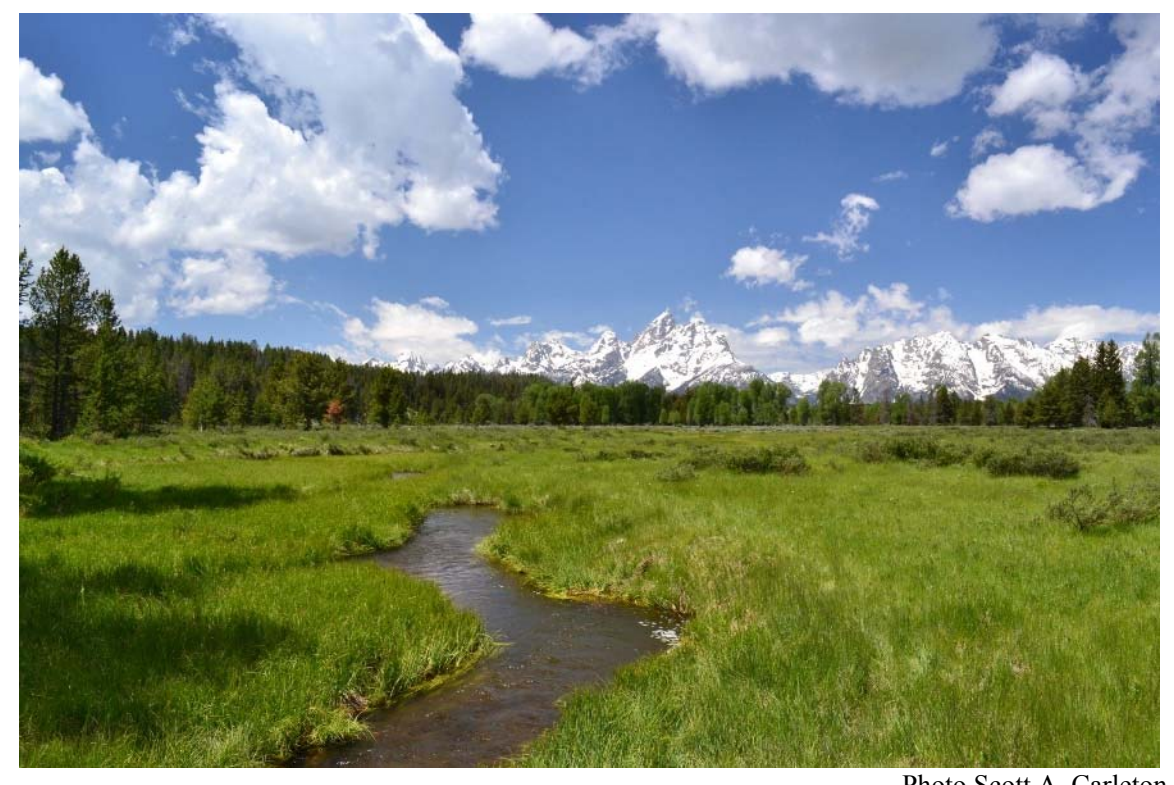

Photo Scott A. Carleton

\begin{abstract}
$\uparrow \quad$ INTRODUCTION
Across their native ranges, cutthroat trout populations are imperiled due to habitat loss, habitat alteration, and introduction of non-native species (Liknes and Graham 1988, Behnke 1992, Hitt et al. 2003). These changes have not gone undetected and a great deal of time and money have been invested in conservation and restoration of cutthroat trout populations (Kershner 1995, USDA 1996, Young and
\end{abstract}

Harig 2002, Baker et al. 2008). The success of these projects is tightly linked to the ability of resource managers to prioritize management efforts. Specifically, where should the investments of time and money br focused to yield the greatest impact on conservation and restoration. This study proposes to use a relatively new, proven analytical tool, stable isotope analysis, to identify differences in the stable isotope signatures of tributary streams entering Jackson Lake. These differences are translated into the tissues, specifically otolith bones, of cutthroat trout 
that use these tributaries during early life stages or upon return for spawning (Kennedy et al. 2002, Muhlfeld et al. 2005, Coghlan et al. 2007, BarnettJohnson et al. 2008, Walther et al. 2008, Ziegler and Whitledge 2010). The ability to link adult trout back to their natal origins and identify where these adults are returning to spawn will provide the data resource managers need to prioritize conservation and restoration efforts in the upper Snake River watershed, with special emphasis on tributary streams entering Jackson Lake.

\section{Why are stable isotopes so useful in expoloring this conservation need?}

Within a watershed, bedrock geomorphology can exhibit a high degree of heterogeneity. This is especially evident in the Rocky Mountains of the western United States, specifically in and around the Grand Teton and Yellowstone National Parks (Figure 1). Geologic heterogeniety of watersheds is the key to understanding the power of isotopic analysis in reconstructing the life histories of fish. Different geologic substrates (granite, sandstones, limestones, etc.) often contain different proportions of elements. Most elements have different forms, called isotopes, and the ratio of these isotope forms changes between rock types and with the age of the rock (BarnettJohnson 2008). Different rock types have variable, yet predictable, abundances of the isotopes of different elements. For example, the element strontium has two stable isotope forms; strontium 86 and strontium 87. As rocks form, they incorporate different amounts of the strontium isotopes. Additionally, as rocks age, radioactive ribidium $(\mathrm{Rb})$ decays to strontium 87 thus altering the abundance of this isotope in the rock. Using new analytical techniques, we can measure these differences and quantify the ratio of the heavier (87) to the lighter (86) isotope of strontium. This is important, because when streams and rivers arise from different geologic substrates within a watershed, they often yield significantly different strontium isotope signatures.

We can indirectly measure the strontium isotope signature of the geologic substrates in a watershed. As water passes over rock or percolates through the ground it slowly erodes the rock and becomes a direct, elemental and isotopic, reflection of the rock type(s) it has passed over and through. Fish absorb the strontium isotope signature of the water directly into their tissues. Fish then become a direct reflection of the water they live in, which is a direct reflection of the geology the water has passed over and through.

One particular tissue in fish that records this environmental signature is an ear bone called an otolith. Fish lay down daily layers in their otoliths that are made up of elements from the water where a fish is currently living. These daily bands accrete into monthly and annual bands that fisheries biologist routinely use to age fish (Huber et al. 1987). Because these bands accumulate daily over the lifetime of a fish, when it moves between isotopically different waters this signature is permanently recorded in the layers of the otolith (Muhlfeld et al. 2005, BarnettJohnson et al. 2008).

Using this approach, we successfully characterized the strontium isotope signatures of tributaries and fish living in these tributaries within the Jackson Lake watershed in 2011 (Carleton 2012). Our success has been directly linked to the heterogeneity of the geology surrounding Jackson Lake and the upper Snake River (Figure 1). This heterogeneity is highly predictive of differences in the strontium isotope signature of tributaries that arise within them and fish that inhabit or use them seasonally.

Now that we have successfully used these differences to differentiate tributaries and the fish living in them, we proposed the current study to: 1) investigate the use of non-destructive sampling methods to characterize strontium isotope values in fish tissues by comparing and contrasting otolith isotope values with scales from the same Snake River cutthroat trout, 2) compare and contrast values from the 2011 study to differentiate tributaries in the Jackson Lake watershed with values obtained from the proposed study to determine repeatability of this work, and 3) use the results of the strontium isotope analysis from water and fish otoliths to describe differences across tributaries that we can then use to link adult and juvenile cutthroat trout in Jackson Lake back to their natal origins and describe fidelity of spawning adults to tributary streams non-destructively. 


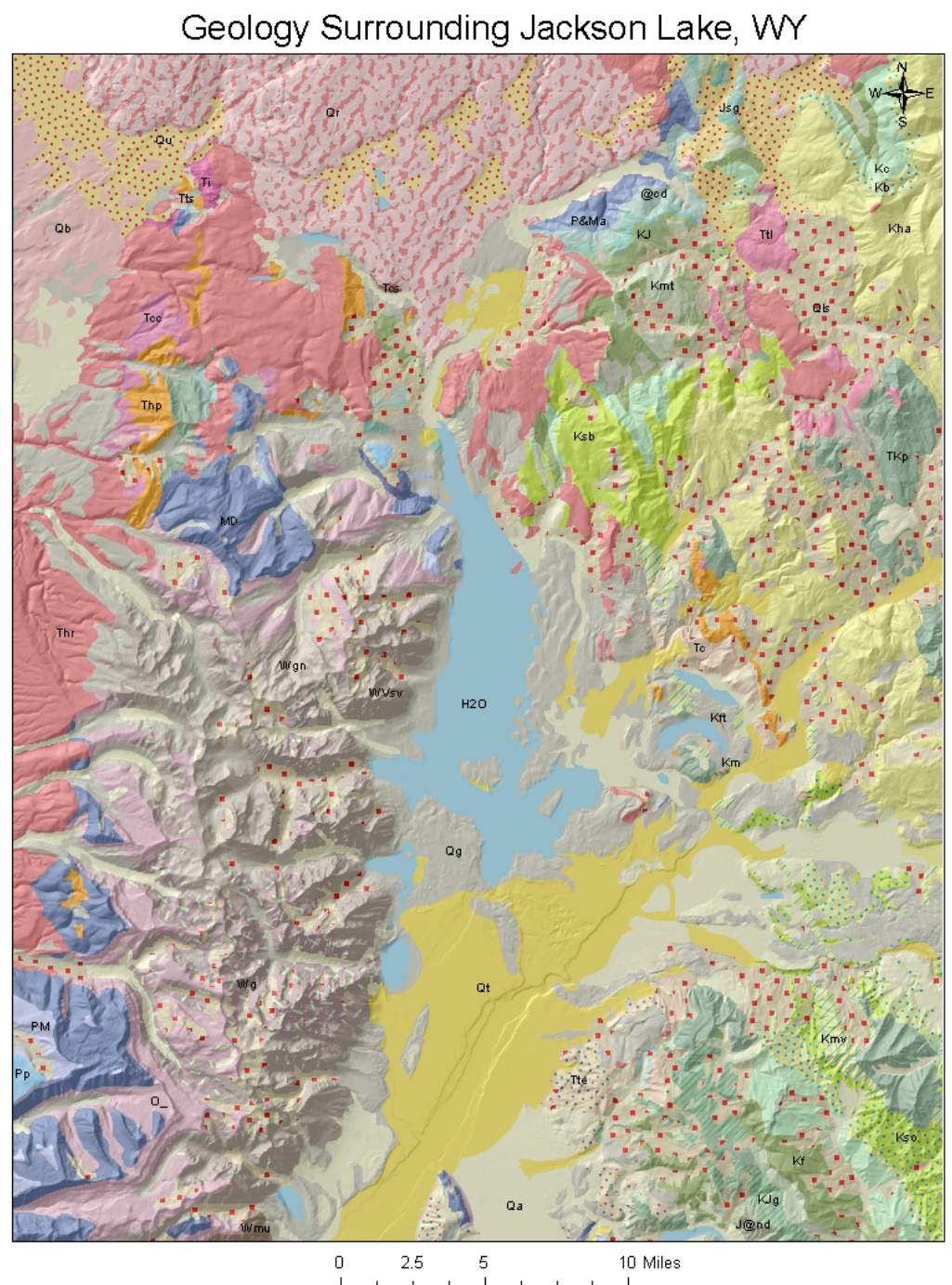

Figure 1. Geomorphological heterogeneity surrounding Jackson Lake, indicated by differences in color and pattern, also indicate possible differences in strontium isotope signatures of waters orginating from these geologic substrates.

\section{$\downarrow \quad$ METHODS}

\section{Fish sampling and otolith analysis}

In cooperation with the Wyoming Game and Fish Department in Jackson, Wyoming, we collected native and non-native trout during annual Jackson Lake sampling work at the end of June, 2013 to obtain otoliths and scales for isotope analysis and we also collected five native or five non-native trout from tributary streams of Jackson Lake using standard hook and line techniques and backpack electrofishing during July - August, 2013. Sagittal otoliths were removed, placed into vials with ultrapure (milli-Q) water and cleaned using an ultrasonic water-bath for 5 minutes to remove tissue. Otoliths were mounted sulcus side up on a microscope slide with Crystalbond
(Crystalbond ${ }^{\mathrm{TM}}$ 509, Ted Pella Inc. Redding, CA) and sanded using a MTI Corporation UNIPOL1210 grinding/polishing machine (1200 grit sand paper wetted with milli-Q water) to reveal the core to the edge.

Laser ablation multi-collector inductively coupled mass spectrometry was used to assess ${ }^{87} \mathrm{Sr}:{ }^{86} \mathrm{Sr}$ in otoliths throughout the life of each fish. Otolith analysis was conducted at the University of California - Davis Interdisciplinary Center for Plasma Mass Spectrometry using a New Wave Research UP213 laser ablation system coupled with a $\mathrm{Nu}$ Plasma HR (Nu032) multiple-collection highresolution double-focusing plasma mass spectrometer system. Line scans across the face of the otolith from the core to the edge generated ${ }^{87} \mathrm{Sr}:{ }^{86} \mathrm{Sr}$ profiles throughout the life of the fish. A scanning speed of 10 
$\mu \mathrm{m} / \mathrm{s}$, laser pulse frequency of $10 \mathrm{~Hz}$, beam width of 40 microns, and $65 \%$ laser power were used. A carrier gas (Helium) was used to carry ablated material into the mass spectrometer where it was mixed with Argon gas before entering the plasma. ${ }^{87} \mathrm{Sr}:{ }^{86} \mathrm{Sr}$ values were normalized in relation to ${ }^{87} \mathrm{Sr}:{ }^{88} \mathrm{Sr}(0.1135)$ to correct for instrumental mass fractionation. ${ }^{87} \mathrm{Rb}$ interference of ${ }^{87} \mathrm{Sr}$ (a possible contaminant found in industrial argon gas) was monitored by measuring ${ }^{85} \mathrm{Rb}$ minimizing interference. Instrumental accuracy was ensured using a modern marine coral (an in-house calcium carbonate standard). By ablating this standard, a comparison was made for each standard run to values known for modern day sea water to account for any instrumental drift throughout runs $\left({ }^{87} \mathrm{Sr}:{ }^{86} \mathrm{Sr}=0.70918\right)$ (Hobbs et al. 2010). Ablations of the standard yielded ${ }^{87} \mathrm{Sr}:{ }^{86} \mathrm{Sr}=0.70920( \pm 0.000098$; $\mathrm{n}=49$ ). Samples were adjusted throughout sessions to known values of the coral standard.

\section{Statistical analysis}

Data from scales and otoliths were analyzed using a paired T-test. Repeatability of strontium in different years was analyzed using a student's T-test. Discriminant function analysis was used to classify tributaries and Jackson lake otolith isotope values.

\section{$\uparrow \quad$ RESULTS}

\section{Field collections}

We collected 23 adult Snake River cutthroat trout and 13 adult lake trout from Jackson Lake and 46 juvenile trout from 10 different tributaries in the Jackson Lake watershed.

\section{Scales}

We had mixed success ablating scales collected from both adult and juvenile trout. Laser power sufficient enough to extract enough material for isotope analysis resulted in the laser ablating through the material and not generating any data. For trout collected from Jackson Lake, we were able to generate data from only 17 of 36 fish due to similar reasons. Strontium isotope values of scales were higher than paired otolith values $(0.7127 \pm 0.0047$ and $0.7100 \pm$ 0.0005 , respectively; Paired $\mathrm{T}=2.41, \mathrm{p}=0.03, \mathrm{~N}=17$ ).

\section{Repeatability and differentiation}

In 2013, we collected juvenile Snake River cutthroat trout, brown trout, and brook trout from 7 of 8 streams sampled in 2011 (Appendix 1). We did, however, obtain samples from three additional tributaries not sampled in 2011 (Appendix 1). Strontium otolith isotope values did not differ between years in 4 of the 7 streams, but did differ in Glade, Arizona, and Lizard Creeks. Differences in the creeks between years was 0.0002, 0.0005, and 0.0001, respectively.

Discriminant function analysis on all 10 tributaries independently was only $63 \%$. Only North Moran Creek, Upper Polecat Creek, and Bailey Creek had $100 \%$ classification rates. Missclassified creeks were grouped based on misclassificaion assignments into AGLU (Arizona, Glade, Lizard, and Upper Sheffield Creeks) and PDQ (Pilgrim, Dime, and Quarter Creeks). Discrminant function analysis on the reorganized creeks improved to $85 \%$. When the reorganized creeks were run with Jackson Lake, classification success decreased to $83 \%$ with one fish from Jackson lake classifiying to the PDQ grouping and 3 of 20 AGLU fish classifying to Jackson Lake.

\section{Natal origins}

Thirteen of the 23 Snake River cutthroat had primordia isotope values that differed from Jackson Lake (Figure 2A). Eighteen of the 23 cutthroat trout had isotope values throughout their life history indicating they had been residents in the system for most of their lives or had edge values that did not differ from Jackson Lake indicating they moved into the lake from somewhere else and had been in the lake long enough for the isotope values to be recorded in the otolith (Figure 2B). Five of the 23 cutthroat had strontium isotope values from the primordia to the edge that never matched Jackson Lake isotope values (Figure 3). One of the 13 lake trout had natal strontium isotope signatures that matched Jackson Lake values, changed dramatically toward the edge, and then shifted back to the value of Jackson Lake at the edge (Figure 4A). A second lake trout had primordia isotope values indicating its natal origins were not in Jackson Lake and then moved into Jackson Lake where it spent the remainder of its post natal life (Figure 4B). The remainder of the lake trout caught in Jackson Lake, 15 of 17, had strontium isotope signatures that did not differ between the primordia and the edge of the otolith (Figure 4C). Visual assignment of Snake River cutthroat trout with natal origins outside of Jackson Lake found that 8 appear to have originated as juveniles from the AGLU group, 2 from the PDQ group, one from Polecat Creek, and 2 have natal primordia signatures that do not match any measured tributaries (Figure 5A and B). 

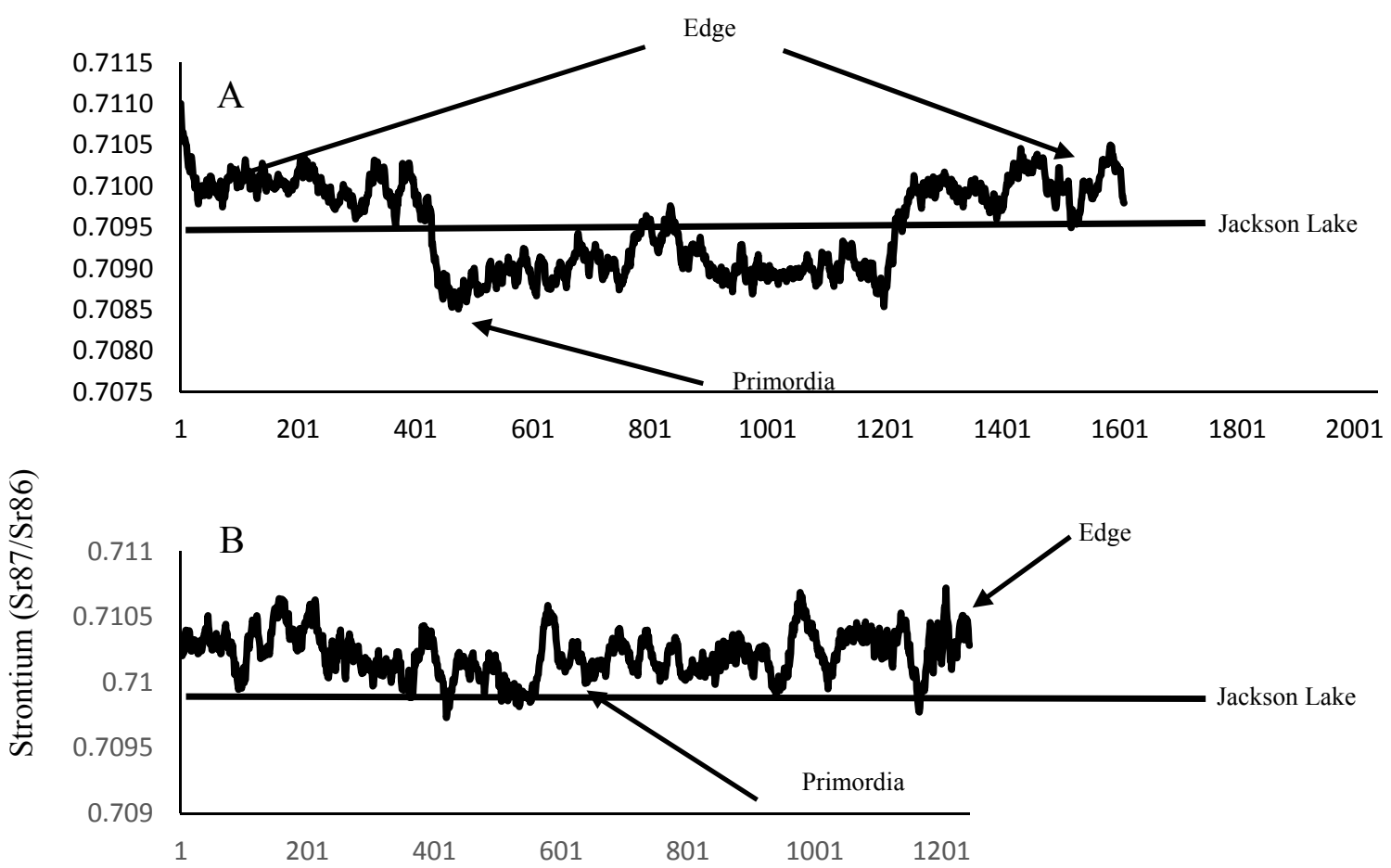

Figure 2. Ablation plots of two representative Snake River cutthroat trout show a shift from a different location of natal origins to the Jackson Lake values (A) and no shift throughout their lifetime (B).

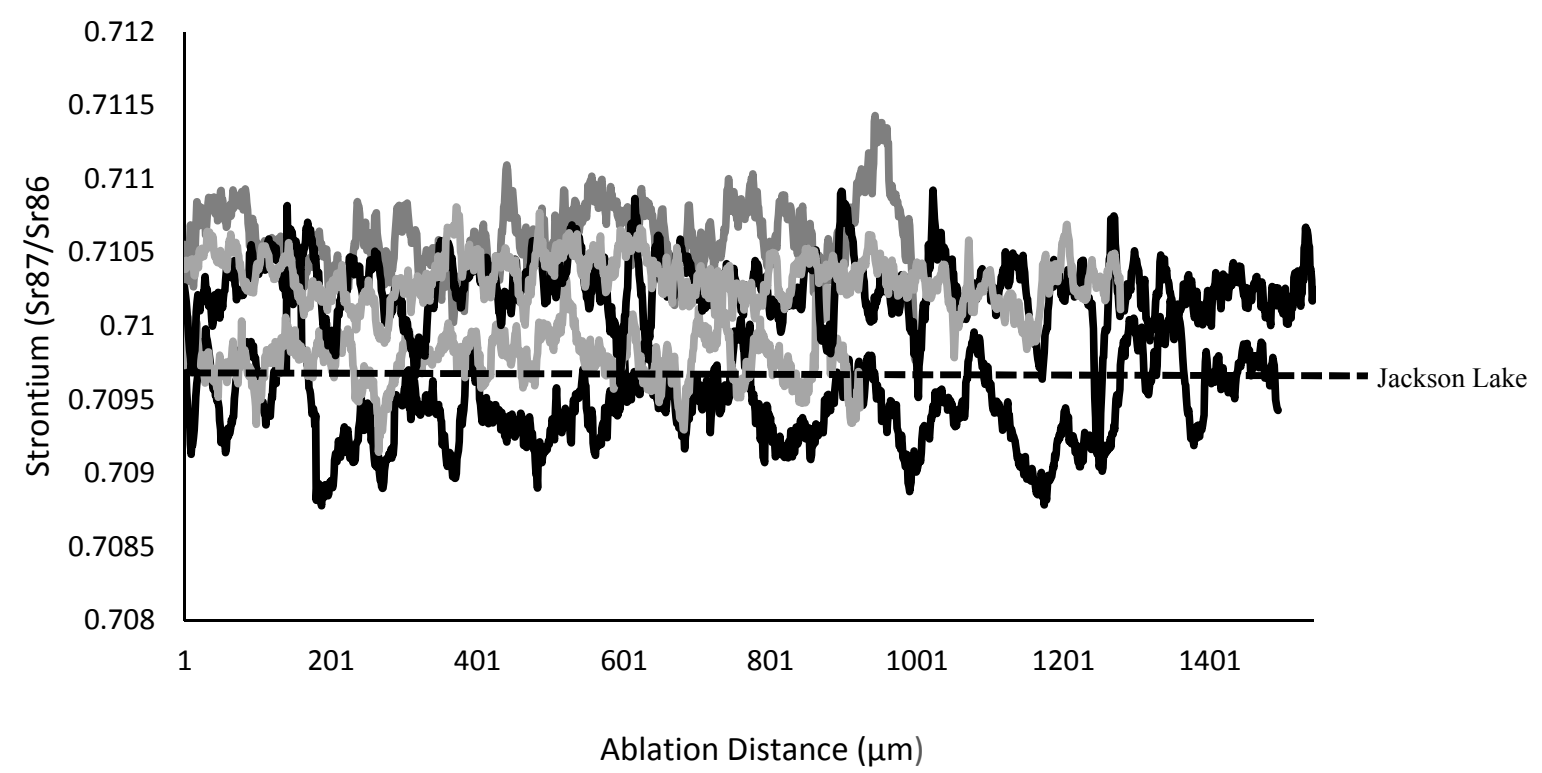

Figure 3. Five of the Snake River cutthroat trout captured have no isotope values that match Jackson Lake indicating they are recent arrivals and have not been in the system long enough to incorporate the lake isotope values into their otoliths. 

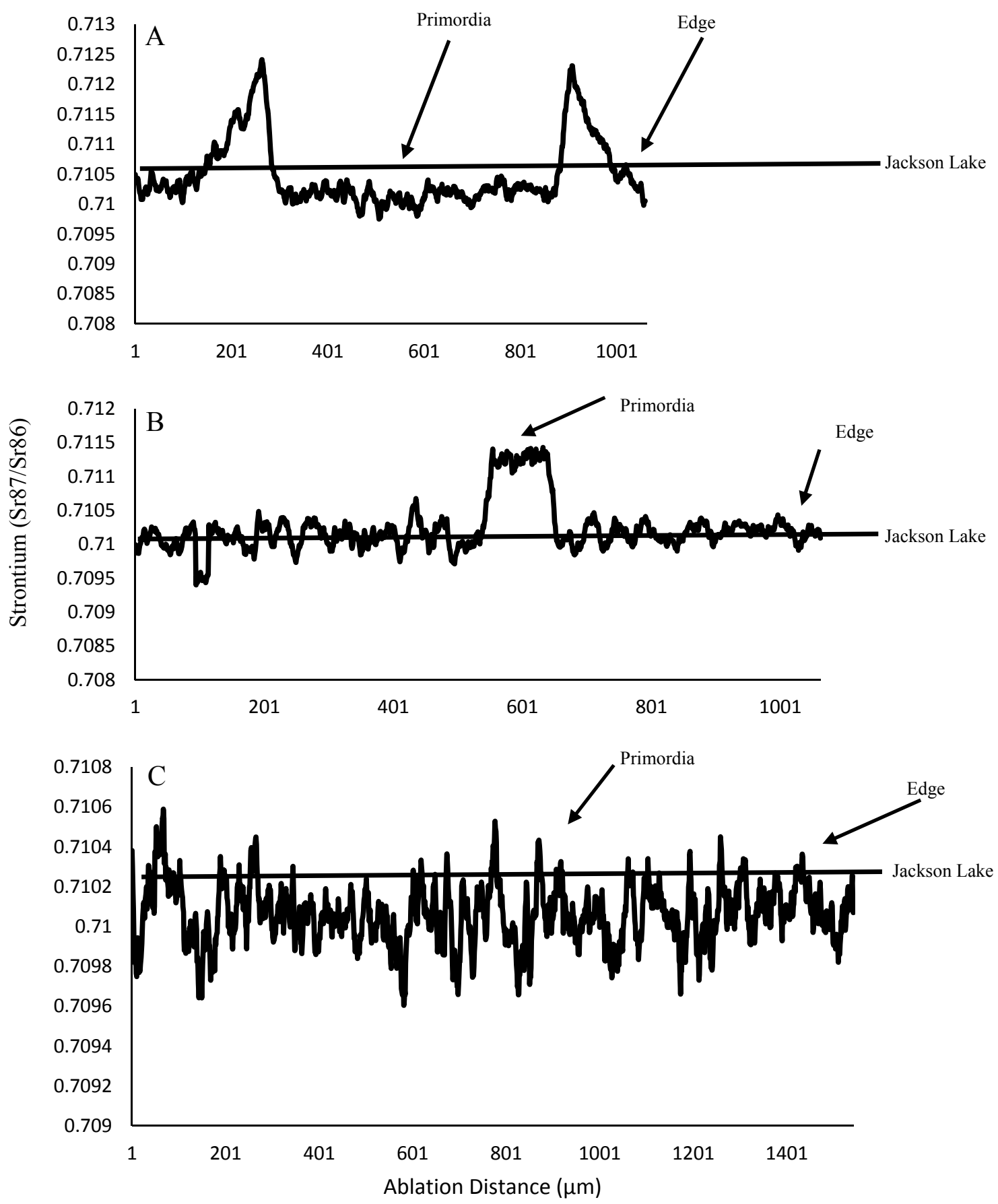

Figure 4. Albation plots of three lake trout show primordia values that indicate natal origins in Jackson Lake, a movement out of the lake at a later age, and then back into Jackson Lake (A), natal origins not in Jackson Lake but movment into the lake at a young age (B), and a lake trout that was born in and has never left Jackson Lake (C). 


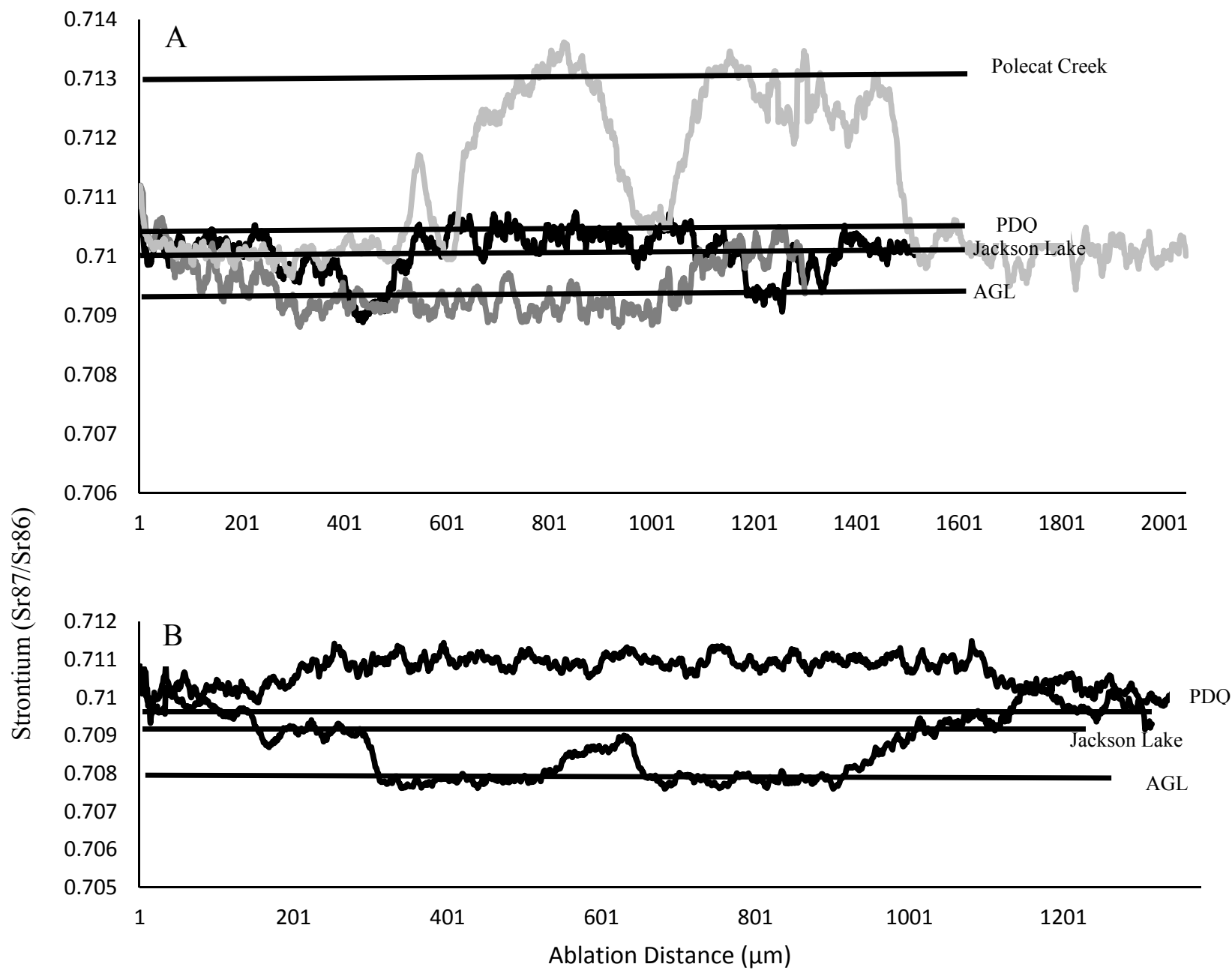

Figure 5. Three Snake River cutthroat trout that have natal values that match streams characterized in the Jackson Lake watershed (A) and two Snake River cutthroat trout that have natal values that don't match streams characterized during this pilot study (B).

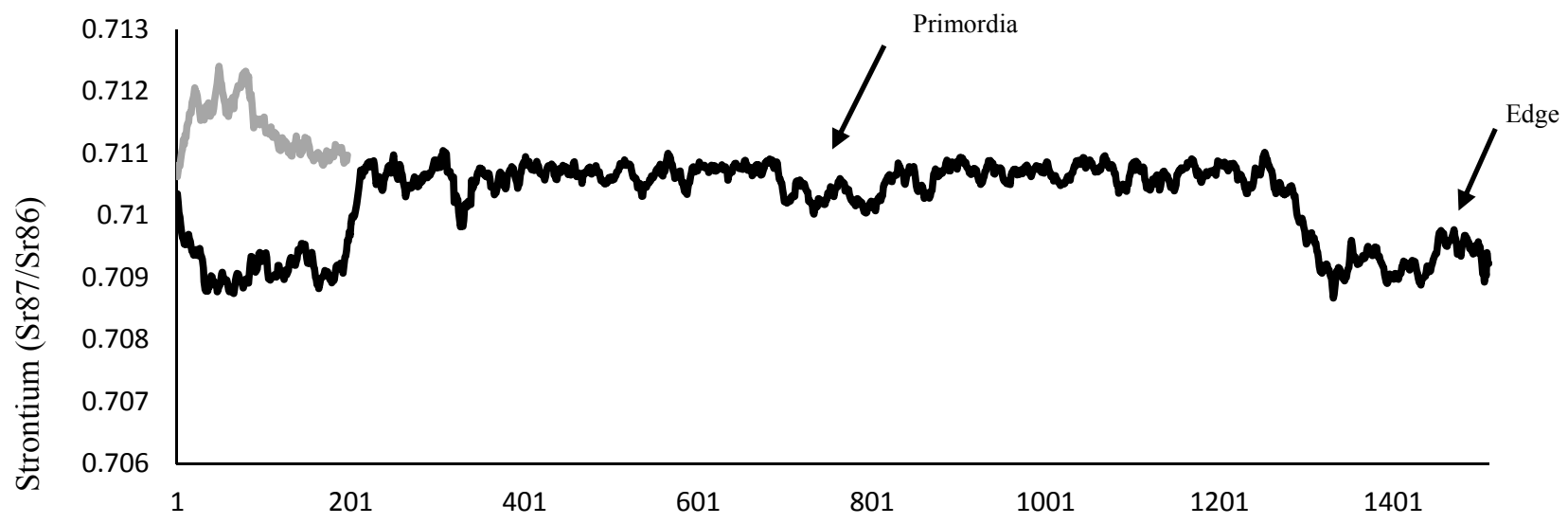

Ablation Distance $(\mu \mathrm{m})$

Figure 6. Laser ablation of otolith (black line) and scale (gray line) demonstrate the offset observed between the two tissue types. 


\section{$\uparrow \quad$ DISCUSSION}

\section{Non-destructive methods}

Scale strontium isotope values differed significantly from otolith isotope values (Figure 6). We know that otolith isotope values very closely resemble the strontium isotope values of the water they live or have lived in throughout their lives (Carleton 2012, Muhlfield 2012). Scale values appear to overestimate the true isotopic value of the water they live in and the variability around these values make it difficult to use scales as a proxy for watershed wide isotopic variation. We are learning from other studies we are currently involved with, that this overestimation is caused by the large amount of phosphates found in scales that are not found in otoliths. When the sample material is introduced into the mass spectrometer, the phosphate groups form aggregations that have similar mass of Sr87. This causes the instrument to overestimate the amount of Sr87 in a sample. We are currently working on a method to minimize this error. At this time, use of scales does not seem to be a viable option to replace otoliths in characterizing watershed isotope values for differentiating fish and assigning adult fish back to their natal origins.

Additionally, even though isotope values are higher in scales, one thing we do not see mirrored in scales that we see in otoliths are the isotopic shifts. Six of the 17 scales were paired with otoliths that showed distinct shifts between the primorida and edge (Figure 6 ). These scales did not show the same pattern, which leads to further skepticism about their use as substitute for otoliths.

\section{Repeatability of watershed isotope values}

Because watershed values are influenced primarily by the rock subtrates water flows over and through, values in these systems should change on geologic time scales. To test this we collected fish from the same locations in 2011 and 2013. Overall, otolith isotope values did not differ between years. However, a few locations yielded differences, albeit small, that had statistically different values (Appendix 1 ). Because much of our inference is at the $3^{\text {rd }}$ and $4^{\text {th }}$ decimal places and because we are dealing with such small sample sizes, we argue that these statistical differences do not translate into biologically significant values. We believe that this method, within the Jackson Lake watershed, has high reproducibility and reliability for future larger scale studies that are needed to better characterize a larger portion of the watershed northward into Yellowstone National Park.

\section{Natal origins}

One of the more interesting inferences we hope to make about the fish in Jackson Lake, especially the Snake River cutthroat trout, is their natal origins. Out of the 23 Snake River cutthroat trout collected in 2013, 13 had natal origins that differed from Jackson Lake isotope values (Figure 3). This is not surprising as we know that cutthroat trout migrate up tributary streams to spawn. Of the 13 cutthroat trout with obvious isotope shifts between the primordia and the edge of the otolith, the largest proportion, 62\%, were from the AGLU grouping, 15\% from the PDQ grouping, one from Polecat Creek, and two from creeks we have not characterized in this system (Figure 5). Our isotope results agree with Stephens (2008) who found most of the creeks on the eastern side of Jackson Lake had the highest numbers of young of year cutthroat trout. What otolith microchemistry allows us to do additionally is put these fish into specific stream groupings, sometimes within specific streams.

What we do find disconcerting in this study is that the groupings do not necessarily follow geographic groupings as predicted. Pilgrim, Dime, and Quarter Creek are at northern and southern ends of Jackson Lake and occupy substrates dominated by different geological rock types (Figure1). On the other hand, Arizona and Lizard are next to each other and in closer proximity to Sheffield and Glade Creeks which lies more with our predictions. It is interesting that Dime and Quarter and Glade and Sheffield are in such close proximity to one another but have significantly different isotope values. Additionally, Bailey Creek which lies between Arizona and Pilgrim also has a unique isotope value, although one could argue that it is fairly similar to the AGLU groupings (Appendix 1). Our only explanation for the disparity in groupings along the eastern portion of Jackson Lake is that the limestone deposits that extend from Glade Creek down to Pilgrim Creek exert a larger influence on water chemistry than initially hypothesized (Figure 1; white and red dotted geologic types). Furthermore, creeks coming out of the west side of Jackson Lake have predictably high strontium isotope values as can be seen in values from North Moran Creek (0.7567 \pm $0.0001)$ and from water values reported by Carleton (2012) that is characteristic of granites.

While there is some disagreement between a couple of groupings in the watershed, one interesting result from this study is that 5 of the 18 cutthroats captured in the lake did not originate in the lake. Specifically, ablations of the otolith did not produce any values from the primordia to the edge that ever 
match Jackson Lake (Figure 3). What this indicates is two different life histories potentially exist for cutthroat trout in Jackson Lake. Some of the cutthroat trout are residents in Jackson Lake and others are seasonally migratory potentially hanging out in the Lake for a short time following spawning (Figure 2B and Figure 3, respectively). We also cannot discount that they might also be new arrivals from upstream towards Yellowstone National Park where the scope and budget for this pilot study have not allowed us to sample and characterize strontium isotope values.

Ultimately, the results of the 2011 and 2013 pilot studies have revealed that strontium otolith microchemistry is a viable tool for differentiating fish in the Jackson Lake watershed and is useful for determining the natal origins of adult cutthroat trout as well as determining whether or not cutthroat trout are residents in the lake itself. We do caution that the results of these studies have been small in scope and sample size and should be used as a launching point to tackle these same questions across the entire watershed from Jackson Lake into Yellowstone National Park, better spatial sampling from tributaries, and increased sample sizes of adult fish from not only Jackson Lake but from the Snake River upstream of Jackson Lake.

\section{ACKNOWLEDGEMENTS}

We thank the Jackson Wyoming Game and Fish Department field crew (Diana Miller, Rob Gipson, Traci Stephens) for their assistance in providing data and field work on this project. We also thank Sue Oney for her assistance during the first pilot study in 2011 and Sue Consolo-Murphy for her assistance and support of this pilot study and this program at the field station. Thank you to the former director Dr. Hank Harlow and current director Dr. Harold Bergman for their support at the research station. Special thanks to Celeste Havener for her work keeping us all in line and on schedule. Finally, we thank the National Park Service for providing the funding for this program.

\section{$\uparrow \quad$ LITERATURE CITED}

Baker, G., N. Darby, and T. Williams. 2008. Bonneville Cutthroat Trout Restoration Project. Natural Resources Report NPS/NRPC/Nrr-2008/055, Great Basin National Park, U.S. Department of the Interior.
Barnett-Johnson, R., T. E. Pearson, F. C. Ramos, C. B. Grimes, and R. B. MacFarlane. 2008. Tracking natal origins of salmon using isotopes, otoliths, and landscape geology. Limnology and Oceanography 53: 16331642.

Behnke, R. J. 1992. Native trout of western North America. American Fisheries Society Monograph 6, Bethesda, MD.

Carleton, S. A. 2011. Identifying tributaries to Jackson Lake important for Snake River cutthroat trout recruitment. University of Wyoming National Park Service Research Center Annual Report 34: 27-32.

Coghlan Jr, S. M., M. S. Lyerly, T. R. Bly, J. S. Williams, D. Bowman, and R. Hannigan. 2007. Otolith chemistry discriminates among hatchery-reared and tributary-spawned salmonines in a tailwater system. North American Journal of Fisheries Management 27: 531-541.

Hitt, N. P., C. A. Frissell, C. C. Muhlfeld, and F. W. Allendorf. 2003. Spread of hybridization between native westslope cutthroat trout, Oncorhynchus clarki lewisi, and nonnative rainbow trout, Oncorhynchus mykiss. Canadian Journal of Fisheries and Aquatic Sciences 60: 1440-1451.

Hubert, W. A., G. T. Baxter, and M. Harrington. 1987. Comparison of age determinations based on scales, otoliths and fin rays for cutthroat trout from Yellowstone Lake. Northwest Science 61: 32-36.

Kennedy, B. P., P. A. Klaue, J. D. Blum, C. L. Folt, and K. H. Nislow. 2002. Reconstructing the lives of fish using $\mathrm{Sr}$ isotopes in otoliths. Canadian Journal of Fisheries and Aquatic Sciences 59: 925-929.

Kershner, J. L. 1995. Bonneville cutthroat trout. Pages 28-35 In: M. K. Young (ed.) Conservation Assessment for Inland Cutthroat Trout. General Technical Report RM-256. U.S. Forest Service, Fort Collins, CO.

Likenes, G. A., and P. J. Graham. 1988. Westslope cutthroat trout in Montana: Life history, status, and management. Pages 53-60 In: R. E. Gresswell (ed.) Status and Management of Interior Stocks of Cutthroat Trout, American Fisheries Society, Symposium 4, Bethesda, MD.

Muhlfeld, C. C., B. Marotz, S. R. Thorrold, and J. L. Fitzgerald. 2005. Geochemical signatures in scales record stream of origin in westslope cutthroat trout. Transactions of the American Fisheries Society 134: 945-959. 
Muhlfeld, C. C., S. R. Thorrold, T. E. McMahon, and B. Marotz. 2012. Estimating westslope cutthroat trout (Oncorhynchus clarkii lewisi) movements in a river network using strontium isoscapes. Canadian Journal of Fisheries and Aquatic Sciences 69: 906-915.

Stephens, T. 2008. Survey of the Upper Snake River Basin upstream of the Pacific Creek confluence, Wyoming. Wyoming Game and Fish Department Fish Division Administrative Report.

U.S. Forest Service. 1996. Conservation assessment for inland cutthroat trout: Distribution, status, and habitat management implications. USDA Forest Service, Intermountain Region, Ogden, UT.
Walther, B. D., S. R. Thorrold, and J. E. Olney. 2008. Geochemical signatures in otoliths record natal origins of American shad. Transactions of the American Fisheries Society 137: 5769.

Young, M. K., and A.L. Harig. 2002. Critique of the recovery of the greenback cutthroat trout. Conservation Biology 15: 1575-1584.

Zeigler, J. M., and G. W. Whitledge. 2010. Assessment of otolith chemistry for identifying source environment of fishes in the lower Illinois River, Illinois. Hydrobiologia 638: 109-119. 
Appendix 1. Strontium isotope values of trout otoliths sampled in 2011 and 2013 show repeatability across years.

\begin{tabular}{|c|c|c|}
\hline Sample Site & 2011 & 2013 \\
\hline Dime Creek & 0.7103 & 0.7100 \\
\hline Dime Creek & 0.7103 & 0.7103 \\
\hline Dime Creek & 0.7103 & 0.7101 \\
\hline Dime Creek & 0.7103 & 0.7100 \\
\hline Dime Creek & 0.7098 & 0.7100 \\
\hline Berry Creek & 0.7108 & . \\
\hline Berry Creek & 0.7105 & . \\
\hline Berry Creek & 0.7108 & . \\
\hline Berry Creek & 0.7103 & \\
\hline Berry Creek & 0.7107 & \\
\hline Upper Polecat Creek & 0.7114 & 0.7129 \\
\hline Upper Polecat Creek & 0.7134 & 0.7128 \\
\hline Upper Polecat Creek & 0.7127 & 0.7129 \\
\hline Upper Polecat Creek & 0.7104 & 0.7131 \\
\hline Upper Polecat Creek & 0.7102 & \\
\hline Pilgrim Creek & 0.7102 & 0.7102 \\
\hline Pilgrim Creek & 0.7103 & 0.7105 \\
\hline Pilgrim Creek & 0.7102 & 0.7105 \\
\hline Pilgrim Creek & 0.7102 & \\
\hline Pilgrim Creek & 0.7102 & \\
\hline Upper Sheffield Creek & 0.7102 & 0.7088 \\
\hline Upper Sheffield Creek & 0.7102 & 0.7100 \\
\hline Upper Sheffield Creek & 0.7103 & 0.7094 \\
\hline Upper Sheffield Creek & 0.7102 & 0.7100 \\
\hline Upper Sheffield Creek & 0.7100 & 0.7100 \\
\hline Glade Creek & 0.7092 & 0.7096 \\
\hline Glade Creek & 0.7092 & 0.7093 \\
\hline Glade Creek & 0.7093 & 0.7095 \\
\hline Glade Creek & 0.7093 & 0.7095 \\
\hline Glade Creek & 0.7094 & 0.7095 \\
\hline Lizard Creek & 0.7095 & 0.7095 \\
\hline Lizard Creek & 0.7095 & 0.7094 \\
\hline Lizard Creek & 0.7095 & 0.7093 \\
\hline Lizard Creek & 0.7095 & 0.7094 \\
\hline Lizard Creek & 0.7094 & 0.709 \\
\hline
\end{tabular}

$\begin{array}{ccc}\text { Sample Site } & \mathbf{2 0 1 1} & \mathbf{2 0 1 3} \\ & & \\ \text { Arizona Creek } & 0.7099 & 0.7093 \\ \text { Arizona Creek } & 0.7099 & 0.7095 \\ \text { Arizona Creek } & 0.7098 & 0.7094 \\ \text { Arizona Creek } & 0.7098 & 0.7093 \\ \text { Arizona Creek } & 0.7098 & 0.7093 \\ \text { Quarter Creek } & . & 0.7108 \\ \text { Quarter Creek } & . & 0.7106 \\ \text { Quarter Creek } & . & 0.7104 \\ \text { Quarter Creek } & . & 0.7106 \\ \text { Quarter Creek } & . & 0.7105 \\ \text { Bailey Creek } & . & 0.7097 \\ \text { Bailey Creek } & . & 0.7097 \\ \text { Bailey Creek } & . & 0.7097 \\ \text { Bailey Creek } & . & 0.7098 \\ \text { Bailey Creek } & . & 0.7097 \\ \text { North Moran Creek } & . & 0.7557 \\ \text { North Moran Creek } & . & 0.7567 \\ \text { North Moran Creek } & . & 0.7593 \\ \text { North Moran Creek } & . & 0.755\end{array}$

